\title{
REAL ESTATE APPRAISAL IN CENTRAL-EASTERN EUROPE: COMPARATIVE ANALYSIS OF POLAND AND SLOVAKIA
}

\author{
Andrej Adamuscin, PhD, Eng. \\ Slovak University of Technology in Bratislava \\ e-mail: andrej.adamuscin@stuba.sk \\ Sławomir Palicki, PhD \\ Poznań University of Economics and Business \\ e-mail: Slawomir.Palicki@ue.poznan.pl
}

Izabela Rącka, PhD

The President Stanistaw Wojciechowski State University of Applied Sciences in Kalisz e-mail:i.racka@pwsz.kalisz.pl

\begin{abstract}
The countries in Central-Eastern Europe have been subjected to dynamic economic changes. Researchers from Poland and Slovakia study the history of the creation of and rules by which the real estate appraiser's profession functions. They also present the methodological basics for property appraisals. The original value of this article is a comparative analysis depicting the similarities and differences occurring in the research area, in two countries from the same region of Europe. The analysis may also influence the methodological discussions of specialists concerning the correctness and purpose of certain approaches, methods or techniques of property appraisal.

The main goal of this article is conducting research on the operational rules of the real estate appraiser profession and property appraisal methods. The detailed objectives include: a critical comparative analysis of the solutions used in the above-mentioned countries, searching for interesting, unusual methodological propositions, and presenting a current assessment of the applied property appraisal methodology.

The foremost methods used in this article are: the analysis of legislative instruments, the analysis of literature concerning property appraisal methodology in Poland and Slovakia, and a questionnaire (CAWI and PAPI technique). Complementary knowledge was derived from official government internet portals and trade associations dealing with property appraisals. A comparative analysis was the basis for conducting research on the similarities and differences in the studied countries.
\end{abstract}

Key words: property valuation, real estate appraiser, real estate.

JEL Classification: D46, R30, R33.

Citation: Adamuscin A., Palicki S., Rącka I., 2017, Real Estate Appraisal in Central-Eastern Europe: Comparative Analysis of Poland and Slovakia, Real Estate Management and Valuation, vol. 25, no. 4, pp. 50-62.

DOI: 10.1515/remav-2017-0029

\section{Introduction}

Real estate appraisers in Poland are natural persons with professional qualifications in the field of real estate appraisal. Such qualifications entitle them to determine the value of all types of property, as well as machinery and equipment which is permanently fixed to the ground. The professional 
qualification of appraisers in Poland was introduced in 1992. Shortly after that, the professional rules in this field were elaborated and introduced into the Real Estate Act of 21 August, 1997. Pursuant to Polish legislation, a real estate appraisal can only be performed by a person having that specific professional qualification (under the threat of putting under arrest or a fine, envisaged by the law). Both business organizations as well as natural persons are entitled to provide appraisal services. An entrepreneur may provide property valuation services as long as he employs at least one valuer.

The format and the contents of the appraisal reports in Poland have been provided for by the Ordinance of the Council of Ministers on real estate appraisal and preparation of valuation reports dated 21 September, 2004.

The main rules applying to appraisers in Poland are: independence, professional objectivity, responsibility, adherence to the principles of preparing valuation reports, special diligence and expertise (PARZYCH, CZAJA 2015).

The stages of acquiring a professional qualification in the field of valuation in Poland are as follows: completing a higher education; postgraduate qualification with specialization in the field of valuation; undergoing a six-month internship; sitting for a state final written and oral certification examination. As of the first quarter of 2017, more than 6,800 natural persons in Poland are holders of a real estate appraiser's certificate (HTTP:/ / MIB.GOV.PL, 12.02.2017).

Appraisers across the country may be members to various professional organizations, such as associations, chambers and others. Such membership is not obligatory, based on free choice of membership to a professional organization. Being a member of one organization does not preclude the possibility of membership in another. Most operating appraisers join regional valuers' associations, which, on their part, are members of the Polish Federation of Valuers' Associations (PFVA). The federation includes 24 regional organizations, representing over 3,500 members. The main objective of the PFVA is creating conditions for improving the skills and qualifications of the appraisers. The Federation also represents its members before public institutions and legislative bodies, observing the implementation of ethical principles in striving towards transparency and working towards facilitating the conclusion of real estate deals across the country. The PFVA is a member of the following international organizations: The European Group of Valuers' Associations (TEGoVA), the International Valuation Standards Council (IVSC), the Central European Real Estate Associations Network (CEREAN), the World Association of Valuation Organizations (WAVO), and the Northern Virginia Association of Realtors, USA (NVAR).

The established regional valuers' associations have the following main tasks: integrating the appraisers' society, organizing training and workshops, conducting preparatory courses for acquiring professional qualifications and internships, etc.

There are two professional organizations for real estate appraisals in Slovakia, i.e.: the Slovak Chamber of Appraisers (Slovenska Komora Znalcov "SKZ") and Slovak Chamber of Real Estate Appraisers and Experts (Slovenská Komora Odhadcov Hodnoty Majetku a Znalcov "SKOHMaZ"). The SKZ was established on 18 June, 2003 as a civic association called the Slovak Association Economic Expert (SAEZ) pursuant to Act No. 83/1990 Association of Citizens, and later, on 14 December, 2007, from the SAEZ arose the Slovak Chamber of Appraisers (Slovenska Komora Znalcov "SKZ"). The chamber has approx. 115 members (natural persons and organizations). SKOHMaZ was established on 19 September, 2012, when it was registered at the Ministry of Interior of the Slovak Republic, and has 186 members (natural persons and organizations) from the field of construction. According to the Ministry of Justice of the Slovak Republic (Jaspi program), there were 836 natural persons holding certificates of real estate appraisers at the end of 2015 in Slovakia. The number of companies holding such certificates and appraising such assets is considerably lower ( 23 companies in total).

Real estate appraisers in Slovakia are natural persons or legal entities with professional qualifications in the field of property valuation. In cases when legal entities carry out such activity, they should hold an appraiser's certificate, similarly as in Poland. Such qualifications entitle them to determine the value of all types of property which is permanently fixed to the ground. The professional rules in this field were elaborated and introduced into Act No. 382/2004 Coll. on Experts, Interpreters and Translators, and on amendment to certain laws.

The main legislative acts regulating property valuation in Slovakia are: 
- Act No. 382/2004 Coll. on Experts, Interpreters and Translators, and on amendment to certain laws.

- Decree No. 490/2004 Coll. of the Ministry of Justice of the Slovak Republic implementing Act No. 382/2004 Coll. on Experts, Interpreters and Translators and on amendment to certain laws.

- Decree No. 491/2004 Coll. of the Ministry of Justice of the Slovak Republic on Awards, Reimbursement of Expenses and Compensation for Wasting the Time of Experts, Interpreters and Translators, as amended.

- Decree No. 492/2004 Coll. on the determination of General Assets Value.

The purpose of these associations is to promote, protect and increase the professional level of appraisers and expert organizations in the performance of expert activities. SKZ and SKOHMaZ is an association of experts, expert organizations and professionals whose activities contribute to the development of expert witnesses. Their activity is focused on the promotion and protection of common interests, as well as coordinating and regulating the activities of its members. They help to create optimal conditions for the performance of expert activities in the Slovak Republic. The activity of the SKZ is directed towards its acceptance in the international structures and acquisition of international knowledge in the field of assessing the performance of expert activities by its members. The SKZ may become associated with legal entities of the Slovak Republic and join international organizations. At present, the SKZ cooperates with the Czech Chamber of Appraisers and, through them, awards Tegova certificates. Furthermore, the SKZ is a member (currently as an observer) of the International Valuation Standards Committee (IVSC) in London.

\section{Literature review}

Protecting the public interest can be assured by authorizing only well-qualified persons who obey professional norms to work as real estate appraisers. It guarantees society the reliability and honesty of real estate appraisers and enables the filing of complaints in cases of duties not being fulfilled within the fixed standards. Trade associations are especially important for society, particularly when they have an impact on skills and performing duties in accordance with the rules (standards of property appraisals, Code of Conduct and Ethics) (SCHULTZE 2007), however, Professional Chambers seem to be more appropriate in these cases.

Trade associations undoubtedly influence the activity of all free professions (Ross, 1974), including real estate appraisers. Although the trade associations organize competitive entities, competing for clients or contracts, and so to a certain extent are conflicted, they also constitute additive value for their members. Trade associations have a significant influence on the members' development, the price level and the quality of service. Taking into consideration the life cycle of a trade association, one can differentiate eight stages (JAFFE 1988):

1. Reorganizational stage. It is a time of developing certain professions. The interest in such professions increases. The educational institutions develop the standards of training specialists, and authorization and certification rules are formalized. Small, local trade associations may be created during this stage.

2. The stage of creation. An association comprising representatives of the same professions within the entire country is created. At this stage, the high effort of well-motivated and prospectivelythinking practitioners is crucial.

3. Original reorganization stage. There are some changes outside and inside the associations that cannot be predicted or prevented, and that is why some associations are not able to conduct business and other, stronger ones, require reorganization. This is a rather short but rather turbulent stage. The associations' predominant aim at this stage is supporting its members with professional literature.

4. Growth and development stage. Operating trade associations start to bring about some tangible effects. The aim of trade associations is to increase the prestige of the profession.

5. Discussion stage. This stage may be difficult for associations, depending on the scale of intervention of other types of professions, to some extent competitive. In the case of real estate appraisers, a competitive professional group might be, to some extent, real estate brokers, who suggest the offer price to their clients, or banks, which establish security interest on the basis of their own analysis. Trade associations publish magazines or bulletins for their members.

6. Subsequent reorganization stage. After a turbulent period, there are usually some changes in the associations' policies. These are sometimes dramatic and, in other cases, instrumental or 
arranged. The idea of implementing limits towards the representatives of the profession that regulate acquiring eligibilities and conducting competitive business becomes important once again. At this stage, a national association often starts monitoring the activity of local groups, to a certain extent introducing control.

7. Fusion and organization stage of new associations. The organizational stage is changed or reorganized for a few coming years. Higher demands concerning the ethics of the profession are introduced and the quality of magazines and other educational materials becomes better. Authorities responsible for professional development are created (professional training, development of professional standards, searching for new methods of work). Cooperation with research and educational institutions is established to improve the foundation of the profession.

8. Maturity stage. This is the last stage, achieved by well-functioning trade associations. There are no political struggles between the members of the association. The operations are aimed at authorities or public entities. A lot of attention is still paid to improving standards of work and ethics. Educational standards are being developed. Funds are raised for conducting research. At this stage, trade associations may want to create their own educational institutions to have exclusive rights to educating and training representatives of the trade in a proper manner. This last stage in the trade association life cycle is, however, not permanent. In times of rapid market and technological changes, there is a possibility of implementing new ideas questioning the existing knowledge and points of view. This fact makes the subsequent development of trade associations possible.

Trade associations created less than 30 years ago in Central-Eastern Europe, including Poland and Slovakia, have probably not reached the maturity stage due to unstable circumstances and the continuous struggle for appreciating the role of a real estate appraiser in the course of property apprising, especially by banks, popularization of standards of the profession and their legal background, as well as refusing the liberalization of closed professions. The following operational principles are emphasized, regardless of the current stage of the trade association:

- creating conditions for professional development - continuous training is obligatory in countries where the real estate appraiser profession and other professions connected with the estate market have a long tradition (ANTONIADES 2012);

- creating and respecting the standards of the profession - clear and enforceable standards create, among other factors, the foundation of the profession, defining the rules for property appraisal (CLOSER 2007). They also enable the analysis of appraisal reports established by other real estate appraisers (DURKIN 2016);

- creating and respecting the Code of Conduct and Ethics - the real estate appraisers who do not fulfil their duties in a proper way or are accused of discharging professional duties or even fraudulent activities should be subjected to professional liability. The victim may claim civil and criminal punishments (LEVINE 2015);

- establishing or the will to exert influence on the rules concerning the acquisition of rights allow for fixing the conditions of practicing the profession to assure good quality of appraisal services. Any actions aimed at confirming or extending the authorizations may also be performed (WAKELING, CAMERON 2011).

Following the specifics of Polish legislation, and, in particular, article 150 of the Real Estate Act, the value of real estate can be its market value, replacement value, cadastral value, or other types of value.

Market value is determined in relation to properties which can be traded (KONOWALCZUK, 2014). This value is the most probable price that can be obtained on the real estate market, having taken into account the price levels of previously realized deals, and under the following assumptions: the parties are independent of each other, do not act under pressure and are willing to conclude a deal; the parties have sufficient time to negotiate, according to the market conditions. The market value is determined without taking into consideration the property related sale-and-purchase costs, as well as any additional taxes and fees.

Replacement value is determined with respect to the current condition of real estate in use, taking into account the fact that they cannot be traded on the market, whereof some specific regulations have to be resorted to. Replacement value is equal to the price that would be paid for the recovery of an asset, taking into account its level of wear and tear. 
Cadastral value is related to the provisions on determining the taxes payable with respect to a given real estate. This value is determined on the basis of estimates of real estate representative for various types of properties in the area of the municipality.

Other types of values in Poland may include: mortgage loan value, investment value (depending on the specific requirements of a particular investor), fair value for accounting purposes, etc.

The methodology of real estate appraisal in Poland includes applying various approaches, methods and techniques. The legal provisions in relation to this methodology include the following three hierarchical levels (ŻAK 2012):

- the Real Estate Act - providing regulation on various types of values, the related terminology, as well as evaluation approaches;

- ordinance of the Council of Ministers on real estate appraisal and preparation of valuation reports dated 21 September, 2004 - determining the methods and techniques of valuation, providing detailed instructions on the various types of appraisals and valuations, as well as on the format and contents of the appraisers' reports;

- Professional Valuation Standards - providing rules on practicing the appraiser's profession.

Currently, the implementation of the majority of professional standards in Poland is not mandatory, except for the standard "Valuation for Securing Debts", which is compulsory for all appraisers pursuant to an Ordinance of the Minister of Infrastructure, dated January 8, 2010.

Three main valuation approaches are recognized worldwide: the market approach, income approach and cost approach. The definitions of these approaches provided by the IVS can be accepted as accurate. Based on the IVS definition, the market approach provides an indication of value by comparing the subject asset with identical or similar assets for which price information is available. The income approach provides an indication of value by converting future cash flows to a single current capital value. The cost approach provides an indication of value based on the economic principle that a buyer will pay no more for an asset than the cost of obtaining an asset of equal utility, whether by purchase or by construction.

However, unlike the IVS approaches on real estate appraisals, the so-called combined approach is also applied in Poland. It is resorted to whenever it is impossible to implement any of the above considered valuation approaches. The underlying methods related to this combined approach are: the residual method (regarding land plots with prospects for future development), demolition costs method (applied to real estate for demolition, whereas the value of land is deducted from the demolition costs of real estate components, while adding the value of materials remaining after demolition), method of estimated land indicators (appropriate in the case of valuations in the field of agriculture and forestry, in the absence of information on market deals; the method involves a sample ratio of a unit of land to the price of a unit of production).

In Slovakia, there are two types of property value - general and yield value. General value is the objective value of buildings and properties. It is an expert assessment of their most probable market price achieved on the valuation date under conditions of free competition, fair trade, between a willing buyer and a willing seller in an arm's length transaction, after proper marketing and where the parties had each acted knowledgeably, prudently and without compulsion, under the presumption that the price was not influenced by an inadequate motive. Yield value is an expert assessment of the present value of future disposable income acquired from property rental after deducting the riskadjusted discount rate. The regulation states that the methods of determining the general value of land and buildings are not the same; therefore, these two processes are further described independently (ADAMUSCIN 2010).

The general value of land is established using three approaches (REGULATION... 2004):

- the sales comparison approach,

- the income capitalization approach (used for lands which are able to generate revenue from rental),

- the method of positional differentiation.

The selection of an appropriate method is performed by an expert and must be justified. According to the purpose of the expert valuation report, several methods can also be used simultaneously, but only one of the values, i.e. the best-suited to the definition of market value, can be presented.

In the sales comparison approach, price calculation is undertaken using a transactional approach. At least three other lands are used for comparison and the metric unit of 1 square meter is assumed. Differences in the compared lands and the appraised land must be taken into account. The documents 
used for comparison (transaction contract, real estate agency bid) must be identifiable. Statistical mathematics can also be used for calculating the price, but the sample has to be large enough in accordance with the specific statistical method applied.

The income capitalization approaches are calculated as capitalizations of future withdrawable resources within an unlimited time frame. The minimal interest rate (in percentage) used in calculations is equal to 1.5 times the base interest rate of the European Central Bank. Taxable income is also taken into account when assigning the interest rate.

The method of positional differentiation outlined only deals with determining the general value of non-agricultural, non-woodland land in a built-up city area, and the general value of building land not yet build-up. General value of land determined using the "method of positional differentiation" is calculated as land size (in square meters) multiplied by the unit general value of land. Unit general value of land is calculated as the initial unit value of land [VHMJ] (compare: Table 1) multiplied by the coefficient of positional differentiation.

Table 1

Town/city classification in Slovakia

\begin{tabular}{ll}
\hline Town/ city classification - name or entry based on citizen count & VHMJ [€/m2] \\
\hline a) Bratislava & $66, .39$ \\
\hline $\begin{array}{l}\text { b) Regional cities: Nitra, Prešov, Trenčín, Trnava, Žilina, Košice, BanskáBystrica a } \\
\text { mestá: Piešt́any, VysokéTatry, Trenčianske Teplice }\end{array}$ & 26.56 \\
\hline c) Cities: Poprad, Zvolen, Liptovský Mikuláš, Martin & 16.60 \\
\hline d) Other district towns with regional or district state bureaus & 9.96 \\
\hline e) Other towns above 15000 citizens & 6.64 \\
\hline f) Other towns between 5000 and 15000 citizens & 4.98 \\
\hline g) Other towns between 2000 and 5000 citizens & 3.32 \\
\hline h) Other towns up to 2000 citizens & 1.66 \\
\hline
\end{tabular}

Source: Regulation of Ministry of Justice of Slovak Republic No. 492/2004 Coll. determination of General Assets Value.

The initial unit value of towns and surrounding areas for which there is a high market demand (for purposes of residency or recreation) can be as high as $70 \%$ of the unit initial value of their respective city.

In the case of interest in other types of real estate, their initial value can be up to $50 \%$ of the unit initial value for their respective city (the city being the driver of interest). In these cases, the coefficient of positional differentiation is related to the city that is the driver of interest.

The positional differentiation coefficient is calculated as a result of six indexes describing the impact of localization and other factors influencing the value of land (REGULATION..., 2004):

- the general situation index, divided into eight classes from 0.70 to 2.00,

- the intensity of use index, divided into seven classes from $0, .90$ to 2.00,

- the traffic relations index, divided into six classes from 0.80 to 1.20 ,

- the business or industry location index, divided into five classes from 0.90 to 2.00 ,

- the land type and provision index, divided into eight classes from 0.60 to 1.50,

- index of advantage or disadvantage factors (divided into two classes: factors of advantage from 1.00 to 3.00 , and factors of disadvantage from 0.20 to 1.00).

Factors of advantage: land determined by a respective development plan to be used for a higher purpose than its current use, corner parcels for commercial use, land with a building permit in protected territory, business parcels in places of high tourist traffic (if not accounted for in the general situation index), land in substantially high market demand (if not accounted for in the initial value of the land), areas with significant tax breaks, etc. The factors of advantage or disadvantage are usable only if they have not already been taken into account in the initial land value or other coefficients.

Taking all of these factors into account, the resulting value of the positional differentiation index of land can vary greatly. It is, therefore, limited by a minimal and maximal value: $\min =0.054$ and $\max =43.200$.

The general value of buildings is determined with three methods:

- the sales comparison approach,

- the method of positional differentiation, 
- the income approach (or the combined method), used for buildings which are able to generate revenue from rental.

In the sales comparison approach, price calculation is undertaken using a transactional approach. At least three other land plots and buildings are used for comparison. Varying metric units which take into account the differences of compared and appraised objects - built -up area, built-up space, floor area, length, piece, etc., are used

In the method of positional differentiation, the general value of buildings is calculated as the technical value of a building factor multiplied by the localization differentiation index which describes the impact of localization and other factors influencing the value of a building.

Technical value is an expert estimate of the initial building value reduced by a value correspondent with building deprecation. Initial value is an expert estimate of the value for which the building was acquirable through construction at the time of the estimation without tax.

Calculation the initial value is done based on budget coefficients. The budget coefficient must be verifiable, meaning that the selected coefficient is identified by name, a respective number in the buildings classification codebook and a base unit value determined according to publicly accessible catalogues issued by the respective ministry. The unit value is modified in a verifiable manner based on the various characteristics of the evaluated object (floor height, yardage, available facilities within the object, construction and material characteristics, etc.). These factors are transferred into the price (their value correspondent with the date on which the appraisal is made).

Initial value is then assessed as a factor of budget coefficients and units of measure. This value is further modified by six correctional indexes:

- Index describing the changes in construction costs between the date of the appraisal and the period for which the budget coefficient of a compared object was made.

- Index describing the impact of the facilities available within the evaluated object. It deals with the price difference between the costs of construction and facilities of evaluated and compared objects.

- Index describing the impact of the built-up area surrounding the evaluated object. It describes the difference between the costs of construction and facilities dependent on the built-up area compared to the average built-up area of a compared object.

- Index describing the impact of the floor height of the evaluated building. It describes the price difference of the evaluated costs of construction and facilities depending on its height compared to the average height of compared buildings.

- Index of construction-material characteristics. It describes the price difference based on the material used for the supporting structure of the building.

- Index describing the territorial impact. It describes the increased or reduced costs of construction at the specific location on the grounds of transportation distances, possibilities of facilitate access to the construction site, etc.

In the income approach (or the combined method) the expert determines the general value of a building as a weighted average of the yield value and technical value of the building. The yield from land is not included in the building yield value. In cases when the building yield value and building technical value are roughly the same, or the yield value is higher than the technical value, the scales rectifying both values are the same. In all other cases, the rectifying scale of building yield value is higher than then rectifying scale of building technical value.

Table 3 shows a summary of the information regarding the possibilities of applying the appraisal approaches in Poland and Slovakia. Based on the data provided, we can arrive at the conclusion that the comparison and market approaches are used most often in both countries, whereas the cost and combined approaches are applied less frequently.

Table 2

Main sources of information related to the process of property valuation in Poland and Slovakia

\begin{tabular}{lll}
\hline \multicolumn{1}{c}{ Poland } & \multicolumn{1}{c}{ Slovakia } \\
\hline - authenticated deeds (including those0 held & - & cadastral portal - data about the ownership \\
by housing cooperatives, for the sale of & & of property and land plot registers; \\
property and cooperative rights to premises; & - & municipality data about property tax \\
- land plot registers; & - & data on spatial planning \\
- cadastral data; & - & appraisal tables and charts according to \\
\hline
\end{tabular}


- registry of network utilities;

- registry of 0 authorities;

- information from government agencies;

- energy-saving certificates, etc. applicable acts and decrees

- publications in specialized journals, property newspapers and internet sites;

- program for property valuation "HYPO"

Source: authors' own research based on (Hopfer, Cymerman 2009; Kucharska-Stasiak 2016).

Table 2 shows the possible sources of information concerning the appraisal of real estate in Poland and Slovakia.

Table 3

Applicability of real estate approaches in Poland and Slovakia

\begin{tabular}{|l|l|}
\hline Comparison Approach & $\underline{\text { Income Approach }}$ \\
Residential properties & Office premises/buildings \\
Studios & Retail premises/buildings \\
Garages & Warehouses \\
Retail premises & Hotels \\
Office premises & Gas stations \\
Warehouse premises & Theaters \\
Unbuilt land plots, etc. & Cinemas, etc. \\
\hline Cost Approach & $\underline{\text { Combined Approach }}$ \\
\hline & Fences and improvements in relation to grading \\
and leveling land plots & Land plots with potential for development \\
Destroyed buildings & \\
Water-supply sources, etc. & \\
\hline The method of positional differentiation & \\
\hline (Slovakia) & \\
Residential properties and land plots & \\
\hline
\end{tabular}

Source: authors' own research.

\section{Data and methods}

The aim of the survey was to compare the opinions and expectations of real estate appraisers in selected Central-Eastern European countries. The novelty of the paper is presenting the viewpoint of experts using a questionnaire survey as the research technique. The research was conducted among real estate appraisers in Poland and Slovakia, who commented on the valuation rules in their countries. The questionnaires filled out by the real estate appraisers included questions concerning the influence of professional organizations on comprehensive customer service, access to the profession, real estate appraisers' opinions on state legal provisions regulating access to the profession and their opinion regarding the number of real estate appraisers in the above-mentioned countries. The respondents were asked about the roles of and reasons for the existence of trade associations. Subsequent questions were connected with knowledge of property appraisal methodology used in different countries throughout the world and opinions regarding the necessity to regulate the rules of property appraisal on the national level, as well as the sources of information which should be available during the property appraisal process. The results show the comparative analysis of the compilation Poland-Slovakia surveys, which may be useful not only with regard to research, but also in practice, as they may be helpful for employers and trade associations.

The sample survey was conducted with the use of Computer Assisted Web Interview (CAWI) and Paper \& Pen Personal Interview (PAPI) techniques among 165 real estate appraisers, including 150 Poles and 15 Slovaks. The interview was conducted via the Internet, sending out requests to fill out questionnaires to about 1000 real estate appraisers (about $10 \%$ of sent out questionnaires were sent back) and during appraisers' training sessions or meetings. The questionnaire included 8 questions concerning the respondents' opinions on the profession itself and 5 questions connected with the most significant social-demographic and professional aspects of the surveyed appraisers. The research was conducted in December 2016 and January 2017. 47\% of the interviewees were women and 53\% men. 
Every third person who filled out the questionnaire was between 30 and 39 years of age, half of the group was under and the other half over the age of 40. Every other person had a technical education, every third person - an economic education and every tenth person - a degree in law. The majority of the real estate appraisers became qualified after 2010.

\section{Empirical results}

The real estate appraisers gave very diversified answers to the question concerning the possibility of establishing all kinds of property appraisals with a single qualification. In Poland, $70 \%$ of the surveyed people agreed with such a statement (answers: "I rather agree" and "I agree"), whereas in Slovakia, $86 \%$ presented an adverse opinion (Fig. 1).

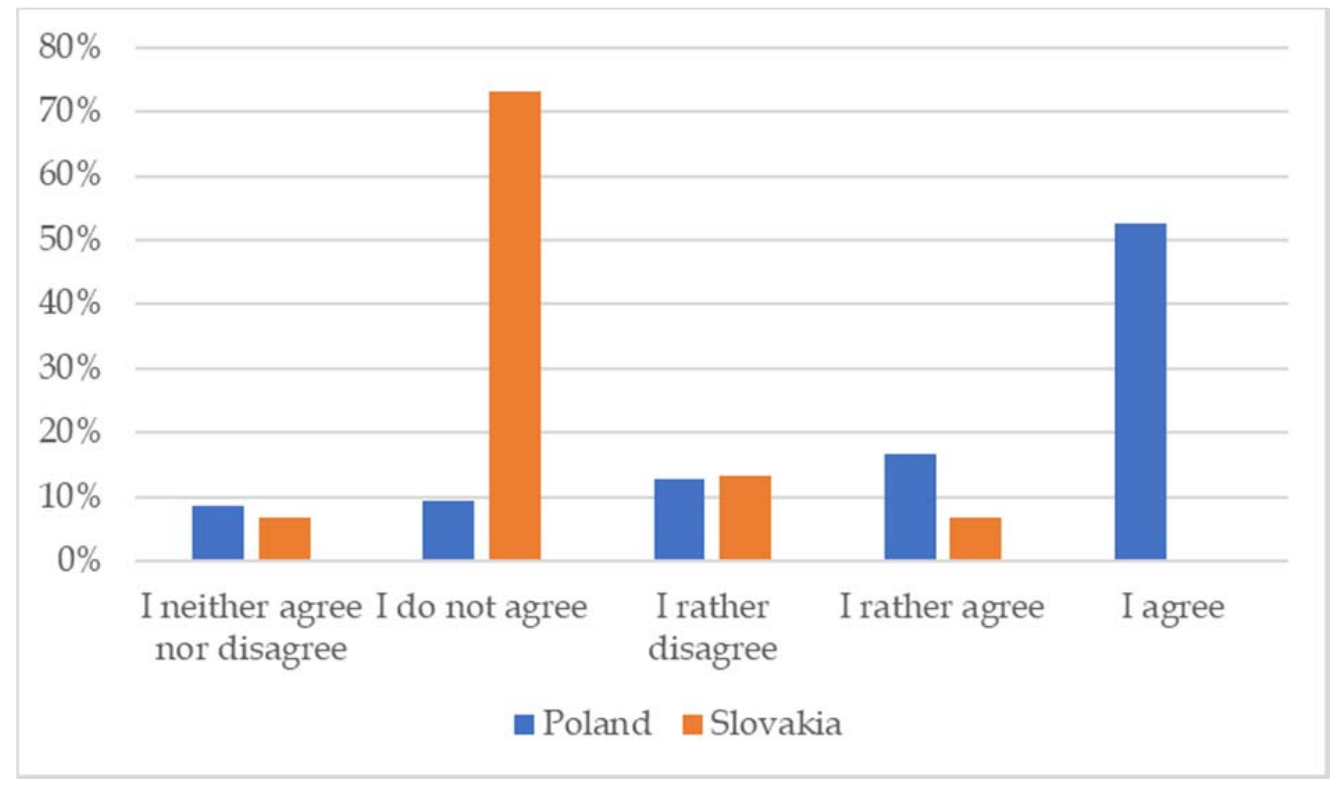

Fig. 1. Opinions on the possibility of establishing all kinds of property appraisals with a single qualification. Source: Composed by authors.

Almost half $(45 \%)$ of Polish real estate appraisers believed that granting a wide range of qualifications guarantees comprehensive customer service, and about $14 \%$ rather agree with this statement. Every fifth respondent did not have an opinion on the topic. Slovak real estate appraisers were less concerned about the comprehensiveness of customer service by people having qualifications to valuate all kinds of real estate; although almost half of the group rather agreed with this statement, $40 \%$ did not respond unambiguously.

Polish real estate appraisers were concerned that granting a wide range of qualifications did not influence access to their profession ( $45 \%$, additionally $18 \%$ were rather concerned), whereas every third Slovak real estate appraiser presented an adverse opinion (additionally $7 \%$ rather agreed that a wide range of qualifications made access to the profession more difficult). The majority of real estate appraisers from Slovakia did not have an opinion on this topic (60\%).

Inspired by the legal system in Bulgaria which regulates a few kinds of qualifications, such as: establishing property appraisal of real estate, machines and devices, companies, agricultural real estate, forest real estate, intellectual and industrial property, financial assets and others, the authors of this research asked the real estate appraisers whether separate qualifications should be conferred for every kind of real estate (Fig. 2). The Polish real estate appraisers strongly objected to such a solution; $53 \%$ of them did not agree with such possibility, and an additional $18 \%$ said to rather disagree. On the other hand, although 53\% of Slovak real estate appraisers did not agree or rather did not agree with this statement, $40 \%$ did not mind such a solution (this being almost three times more than in Poland). 


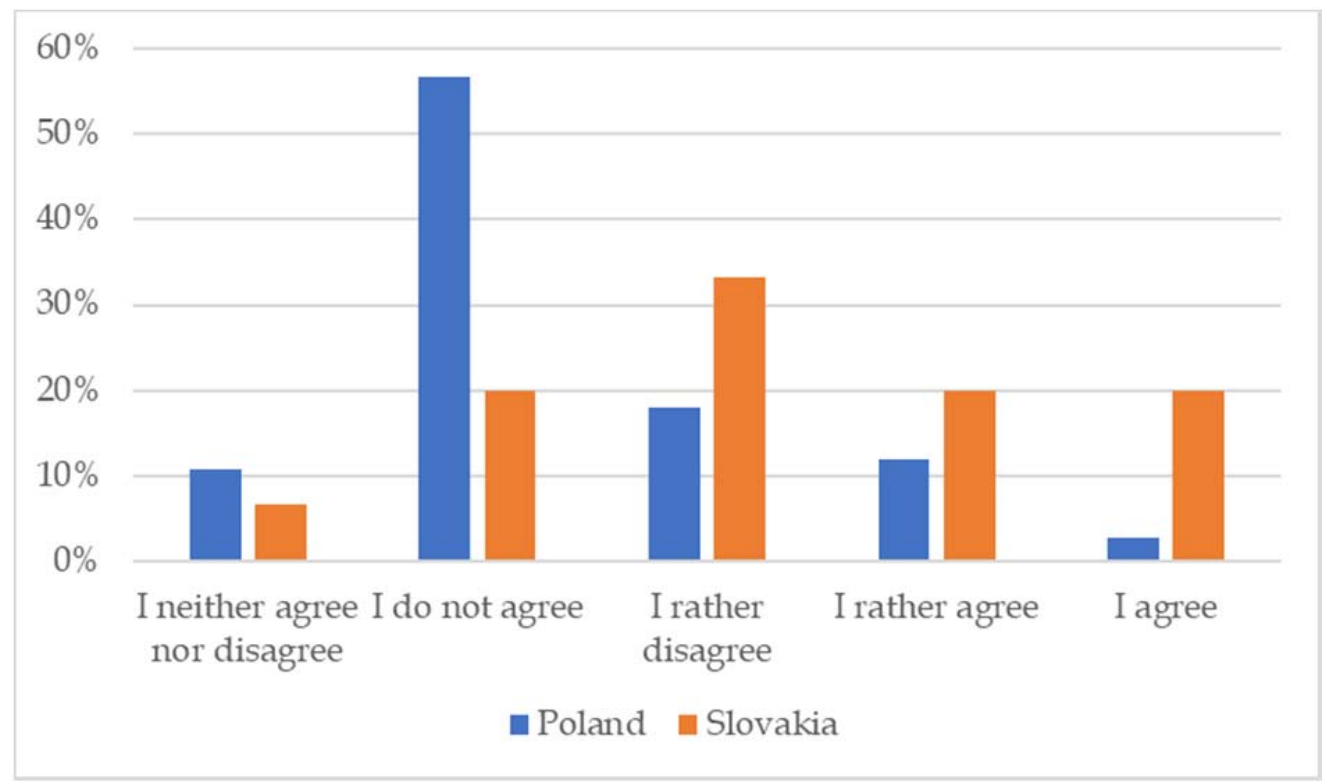

Fig. 2. Opinions on implementing separate qualifications for different kinds of property appraisals. Source: Compiled by the authors.

Furthermore, the answers were analyzed from the perspective of previously collected data (Fig. 1). All Slovak appraisers who claimed that a single qualification should have the power to cover the possibility to valuate all kinds of real estate categorically rejected the proposal of conferring separate qualifications for particular kinds of real estates. In Poland, however, one out of ten appraisers did not have an opinion on the topic, whereas a further $3 \%$ accepted both, conferring a single qualification for all kinds of real estate, as well as separate qualifications for individual kinds of real estate. Interestingly, only half of the people who did not approve of the idea of a wide range of qualifications at the same time opted for conferring separate qualifications for particular kinds of real estate. $9 \%$ of the interviewees did not have an opinion on the topic, however as many as $41 \%$ did not approve of separate qualifications.

Every third Polish appraiser claimed that conferring a narrow range of qualifications guarantees $(13 \%)$ or rather guarantees $(19 \%)$ comprehensive customer service. One fifth of the respondents did not have an opinion on the topic. On the other hand, Slovak appraisers were convinced that comprehensive customer service can be performed by appraisers with a narrow range of qualifications - $20 \%$ of the surveyed rather agreed with the statement and as many as $80 \%$ definitely noticed such a correlation.

More than half of the real estate appraisers did not perceive conferring a narrow range of qualifications as a barrier in gaining access to a professional career $(35 \%$, and an additional $22 \%$ were rather convinced about this). Merely one in four appraisers recognized a narrow range of qualifications as a barrier in gaining access to a professional career.

The extent to which access to the appraisers' profession is regulated by the state is, in the opinion of Polish appraisers, either satisfactory (46\%) or insufficient (39\%) (Fig. 3). Only one in ten appraisers claimed that the conditions of acquiring the qualifications should be mitigated and merely a few (5\%) claimed that access to a professional career should not be regulated at all. Among Slovak appraisers, there is a stronger conviction regarding the lack of necessity to restrictively regulate access to a professional career: as many as $53 \%$ of those surveyed accepted the proposal to limit the barriers in gaining access to a professional career and an additional $7 \%$ claimed that it should not be regulated at all. One fifth of the respondents accepted the currently governing regulations for conferring the qualifications; one fifth did not have an opinion on the topic. 


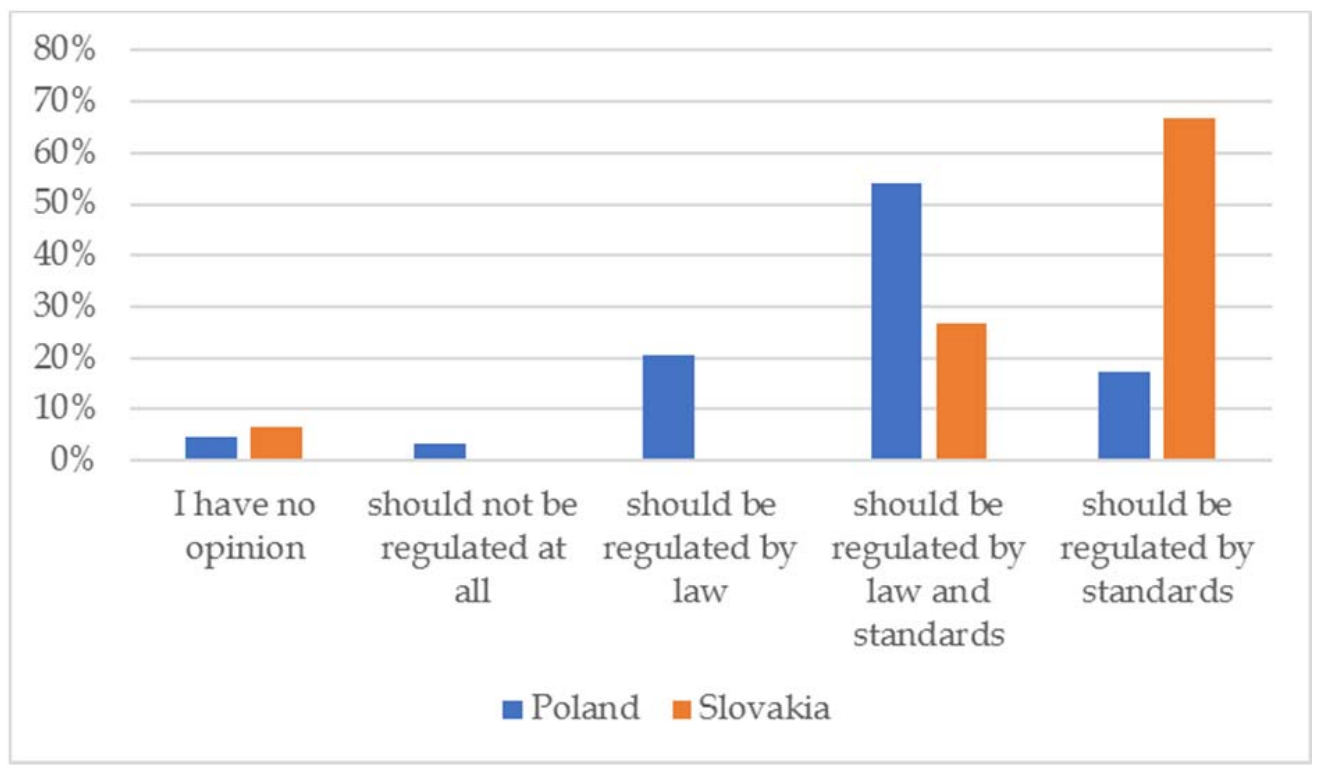

Fig. 3. Opinions regarding the extent of state regulations on gaining access to the profession of real estate appraiser. Source: Compiled by the authors.

In the next stage of the survey, an opinion of Polish and Slovak appraisers regarding the regulation of property appraising rules was researched. Polish appraisers mostly agreed (54\%) that the rules for property appraisal should be regulated statutorily and, at the same time, by professional standards. $21 \%$ of the appraisers were in favor of statutory regulations, whereas $17 \%$ - in favor of regulations by means of professional standards. Merely 3\% of the respondents claim that no regulations are necessary for appraising methods. Slovak appraisers expressed a different opinion, with a quarter declaring that the rules for property appraisal should be regulated both statutorily and by professional standards, and two thirds being in favor of regulating the rules exclusively by professional standards.

Furthermore, based on the statute of the Polish Federation of Valuers' Associations, the appraisers were asked about the role of real estate appraiser trade associations. The respondents were not informed about the source document on the basis of which the possible answers were formulated. They were given the possibility of marking more than one answer. Slovak appraisers indicated particular answers with a similar frequency. In Poland, however, the results were different, with a dominance of several particular answers. According to Polish appraisers, the most commonly selected function of real estate appraiser trade associations is to mediate in conflicts, including those connected with the value of real estate and the correctness of appraisal reports. The frequency of choosing such an answer is twice as high as the average number of answers for other indicated roles of real estate appraiser trade associations. The duties chosen with a slightly above average frequency were:

- creating conditions for professional development,

- working towards legislative solutions,

- securing professional rights,

- ensuring appraisers' development,

- enhancing the prestige of the profession,

- publishing specialist materials.

The roles connected with promoting the profession and maintaining contacts with foreign trade associations were indicated with a below average frequency. A few respondents marked the importance to represent the appraisers' business matters. There were also four "additional" answers: securing copyrights, dealing with dumping, building a positive image of the profession and improving qualifications, which were identical with the propositions offered by the authors of the questionnaire.

The last question addressed to the appraisers in the substantive part of the questionnaire was the admissibility of sources of price information available in the process of property appraisal. It was possible to choose more than one answer in response to this question. The opinions of Polish and Slovak appraisers on this particular topic were rather convergent. More than $60 \%$ of choices in both 
countries regarded transactional prices from notarial deeds as admissible. Three times less often in Poland and five times in Slovakia, appraisers indicated information about transactional prices from real estate brokers. Offer prices were also regarded by some as an acceptable source of information for property appraisals; however, the answer was not particularly popular. Overheard information was accepted by $2 \%$ of the appraisers in Poland and none in Slovakia.

\section{Discussion and conclusions}

The Polish Federation of Valuers' Associations (PFVA), Slovak Chamber of Appraisers (SKZ) and Slovak Chamber of Real Estate Appraisers and Experts (SKOHMaZ) have similar functions and carry out similar activities. However, unlike the Slovak organization, the Polish organization is a member of more international valuers' associations, which can be considered an advantage.

The appraisal practice principles in these countries are almost identical, with few differences. This accounts for the claim that the activities of appraisers worldwide are very similar, thus rendering the implementation of unified appraisal standards possible. For these same reasons, collaboration among individual appraisers' organizations worldwide is of significant importance to their general benefit and development.

Polish and Slovak legislation in the field of valuation activities is extensive and covers a large scope. Should the regulations in Poland and Slovakia be followed closely, it would become clear that a strict hierarchical structure exists in this respect. First, the Property Valuation Act in Poland and Slovakia have determined the foundations of the appraisal process (various value bases, appraisal approaches, terminology, etc.). Second, the Ordinance of the Council of Ministers on real estate appraisal and preparation of valuation reports dated 21 September, 2004 in Poland and Decree No. 490/2004 Coll. of the Ministry of Justice of the Slovak Republic implementing Act No. 382/2004 Coll., on Experts, Interpreters and Translators and on amendments certain laws, as amended in Slovakia determine the specific methods and techniques of valuation, and provide various instructions, as well as the format and contents of the valuation reports. Third, Professional Valuation Standards have been introduced throughout the country.

The effective valuation standards in these countries are recommendatory in nature, while in terms of the differences in the methods used, a distinction is the regulated combined approach to valuation activities in Poland, as well as the use of subcategories (methods and techniques) of the comparison approach.

The main sources of information used in the process of real estate appraisal in Poland and Slovakia are generally similar, excluding these differences: in Poland there is a legal obligation to use authenticated deeds as the one and only source of information on market prices. Appraisers have access to information on all transactions that have taken place (access fee). A specific phenomenon in Polish methodology of property valuation is the mixed approach. Specific to the Slovak methodology of property valuation is the method of positional differentiation. It is a method that is used in property valuation of any type. The real estate appraiser bases valuation on the size and the technical value of the object. When determining the coefficient of positional differentiation, several factors, such as the location of the property in a city, the current technical condition of buildings, facilities, etc., are taken into account.

In summary, there are numerous similarities and a few specific differences in the real estate appraisal systems in the analyzed EU countries, involving the original methodological concepts, differences in the use of data sources in the process of real estate appraisal, and the different requirements necessary for getting qualifications to operate in the field of property valuation. This points to the possibility of further discussion and methodological evolution in the studied area, the seeking of novel, effective solutions aimed at optimizing the use of real estate valuation approaches, methods and techniques.

Furthermore, the main conclusion that can be drawn from the analysis of the questionnaire research is the fact that appraisers are reluctant to provide answers. The low number of filled out questionnaires is common in the case of an Internet study, however, a surprisingly large number of appraisers did not complete the surveys during training sessions or other meetings organized by trade associations (though the number of appraisers questioned, with the materiality level assumption $\alpha=0.05$ and permissible error $e=0.10$, is higher than the minimum sample). 
The respondents in Poland and Slovakia have basically a diverse point of view on the question of conferring qualifications for property appraisal of different kinds of real estate. Polish appraisers prefer a universal solution - one kind of qualification should cover all types of real estate. Slovak appraisers understand the need to differentiate and specialize such qualifications. Almost all of the appraisers in Poland and Slovakia understand the sense behind the operation of real estate appraiser trade associations. Dealing with conflicts, including those connected with the value of real estate and the correctness of appraisal reports, creating conditions for professional development and caring for appraisers' personal development, acting in favor of legislative solutions, securing professional rights, enhancing the prestige of the profession and publishing specialist materials are among the main aims of real estate appraiser trade associations. It appears, however, that promoting ethical values and securing their observation, as well as representing the appraisers' business matters and creating conditions for development are regarded as statutory aims for such associations. The respondents declarations regarding professional standards are also worth pointing out: over 70\% of Polish appraisers and almost all of the Slovak ones considered the standards to be necessary for the profession. In this context, real estate appraiser trade associations should rethink and possibly redefine the role they have in the community, as well as intensify their activity.

\section{References}

ADAMUSCIN A., 2010, The Investment Instruments in Real Estate Market, Bratislava, Statis.

ANTONIADES H., 2012, Continuing Education for the Property Professional in Australia, Inted.

Closer B.M., 2007, The Evolution of Appraiser Ethics and Standards, Appraisal Journal, 75 (2), pp. 116129.

HOPFER A., CYMERMAN R., 2009, Źródła informacji w gospodarowaniu nieruchomościami (Sources of Information in Real Estate Management), Polska Federacja Stowarzyszeń Rzeczoznawców Majątkowych, Warszawa.

DURKIN R., 2016, Appraisal Review - Theory, Risks, and Rewards, Value Examiner, Jan/Feb 2016, pp. 18-20.

JAFFE A.J., 1988, Toward an Evolutionary Theory of Trade Associations: The Case of Real Estate Appraisers, Journal of the American Real Estate \& Urban Economics Association, 16 (3), pp. 230-256.

KONOWALCZUK J., 2014, Wycena nieruchomości do celów kredytowych (Real Estate Appraisal for Credit Goals), Poltext, Warszawa.

KUCHARSKA-STASIAK E., 2016, Ekonomiczny wymiar nieruchomości (The Economic Dimension of Real Estate), Wydawnictwo Naukowe PWN, Warszawa.

LeVInE M.L., 2015, Appraisers: Is the Risk Worth the Reward?, Real Estate Finance (Aspen Publishers Inc.), 32 (1), pp. 10-15.

PARZYCH P., CZAJA J., 2015, Szacowanie rynkowej wartości nieruchomości (Real Estate Market Value Estimation), Wydawnictwa AGH, Kraków.

Regulation of Ministry of JustiCe of SlOvaK RePublic NO. 492/2004, 2004, Coll. Determination of General Assets Value.

Ross H., 1974, The Nature of Professional Responsibilities, [In:] Institutional Issues in Public Accounting, Scholars Book Co., pp. 229-249.

Schultze R., 2007, What does it Mean to be a Self-Governing Regulated Profession?, Journal of Property Tax Assessment \& Administration, 4 (3), pp. 41-53.

WAKEling J., CAMERON N., 2011, The Implications of Enhancing Appraisal to Meet the Requirements of Revalidation, as Perceived by Appraisers: a Qualitative Study in Scotland, Education for Primary Care, 22, pp. 377-85.

ŻAK M., 2012, Wycena nieruchomości (Real Estate Appraisal), Wydawnictwo C.H. Beck, Warszawa.

Internet sources:

http:/ / mib.gov.pl, [access: 12.02.2017]. 